\title{
SYMBOLIC SELF-DETERMINATION: THE CASE OF MALAYSIA AND AUSTRALIA'S INDIGENOUS EDUCATION POLICY
}

\section{Mohd Roslan Rosnon ${ }^{1,2 *}$, Mansor Abu Talib ${ }^{3}$ and Mohamad Naqiuddin Dahamat Azam ${ }^{3}$}

\author{
${ }^{1}$ Department of Social and Development Sciences, Faculty of Human Ecology, \\ Universiti Putra Malaysia, Selangor, MALAYSIA \\ ${ }^{2}$ Institute of Social Sciences, Universiti Putra Malaysia, Selangor, MALAYSIA \\ ${ }^{3}$ Department of Human Development and Family Studies, Faculty of Human \\ Ecology, Universiti Putra Malaysia, Selangor, MALAYSIA
}

*Corresponding author: roslan_rosnon@upm.edu.my

Published online: 30 April 2021

To cite this article: Mohd Roslan Rosnon, Mansor Abu Talib and Mohamad Naqiuddin Dahamat Azam. 2021. Symbolic self-determination: The case of Malaysia and Australia's indigenous education policy. Kajian Malaysia 39(1): 25-53. https://doi.org/10.21315/km2021.39.1.2

To link to this article: https://doi.org/10.21315/km2021.39.1.2

\begin{abstract}
The United Nations Declaration on the Rights of Indigenous Peoples (UNDRIP) outlines the right to self-determination for indigenous peoples. To what extent this right to self-determination is practised in Malaysia and Australia is the focus of this study. Therefore, this article examines to what degree indigenous peoples' rights to self-determination are encompassed in the formulation and development of indigenous education policy that has been recognised and supported. In-depth interviews were conducted with 24 respondents consisting of policy makers, educators, and non-governmental organisations (NGOs) personnel in Malaysia and Australia, including indigenous scholars. The findings show that Australia's Aboriginal and Torres Strait Islander people were more actively involved in charting their educational policies than indigenous peoples in Malaysia. Among Malaysia's Orang Asli, there was limited negotiation as a facilitating component of self-determination and there was also limited recognition of indigenous rights in determining education policy.
\end{abstract}

Keywords: self-determination, indigenous peoples, indigenous education policy 


\section{INTRODUCTION}

In indigenous communities, self-determination is crucial for successfully resolving issues at every level of the education system and in educational programmes. The right to self-determination is multifaceted and includes the community's involvement in the promulgation and determination of teaching methods, curriculum and materials, as well as in the appointment of teachers (King and Schielmann 2004, 20). This inclusion of self-determination is to ensure the policies are consistent with the views that indigenous peoples have about the role of education in their lives.

Self-determination is an important element of educational participation because understanding how this occurs is crucial for any examination of the development of policy and programmes in the scope of indigenous education. Through participation, indigenous peoples can take control of their education system. In this process of gaining control, empowerment is explored as an important element. Empowerment in these contexts refers to the ability of indigenous peoples to make decisions for themselves. King and Schielmann (2004) assert that the quality of an indigenous education system is closely related to the participation of indigenous peoples in decision-making, planning, as well as the design and implementation of education programmes. Hasan (2009) recommends the involvement of indigenous communities as an important factor in planning their future development to meet their needs, thus emphasising the importance of indigenous participation. King and Schielmann $(2004,32)$ outline the following important elements:

1. Participatory processes to elaborate and determine pedagogy, curricula, resources and school calendars, as well as the appointment of teachers;

2. The involvement of indigenous consultants and teachers, particularly in first language instruction in early childhood and primary education;

3. Meaningful indigenous representation on school boards and policymaking committees, as well as in the institutions of the state education system; and

4. Support for the implementation of the educational plans, programmes, curricula and resources of indigenous peoples, and the establishment of their own educational institutions to enhance their responsibility and ownership over teaching practices and contents. 
Malaysia and Australia are two countries that have indigenous populations and share similar structures in their education systems. Both countries have education systems with a mainstream orientation (i.e., national education system). But at the same time, there is very little consideration given to educational requirements within the cultural context of indigenous peoples (Mohd Roslan 2016a; Mohd Roslan and Chinnasamy 2015). Therefore, this article aims to clarify indigenous peoples' right to self-determination in the formulation and development of indigenous education policy.

\section{Indigenous Education Policy in Malaysia and Australia}

There has been much research, reporting and theorising about indigenous education and the factors that affect the educational outcomes of indigenous students. ${ }^{1}$ Prior studies point out that government delivery of education to indigenous peoples have been problematic (Champagne and Ismael 2006; Hasan 2009; Mohd Roslan 2014; Mohd Roslan, Mansor and Nik Alia Fahada 2019; Sidwell and Roger 2011). The discrimination in the implementation of educational policy is still considered to be the main issue that leaves indigenous peoples in education systems lagging far behind (Buckskin 2009; Hasan 2009; King and Schielmann 2004; Mohd Roslan 2014). Lower levels of participation and recognition of indigenous peoples' rights in education policy are some examples of discrimination that can bring negative impacts to indigenous students (Ah Sam and Ackland 2005; Buckskin 2009; Gray and Partington 2012; Hasan 2009; Mohd Roslan 2014; 2016a; Mohd Roslan, Mansor and Nik Alia Fahada 2019; Sharifah et al. 2011; Sidwell and Roger 2011).

In Malaysia, the progress and development of the Orang Asli through education is significant in many aspects. ${ }^{2}$ Asnarulkhadi et al. (2007) argues that the context of the physical growth of infrastructure and modern agricultural methods introduced by the government has improved the quality of life and education of the Orang Asli. These types of efforts are not new from the perspective of the Malaysian government, which has introduced initiatives to integrate minority groups into the mainstream culture and this measure fulfils aspirations for social participation (Asnarulkhadi 2005; Sarjit, Mohd Roslan and Ma'rof 2010). These initiatives constituted part of the Second Malaya Plan (1961-1965) through to the Tenth Malaysian Plan (2011-2015). ${ }^{3,4}$ In Malaysia, indigenous truancy contributes to the problem of poor educational attainment. Among the earliest studies were those by Hasan (2009), who found that children from indigenous communities were unwilling to attend school because of misgivings and embarrassment that arose from an educational system that was not compatible with their culture. The decline in indigenous education was then due 
to the shortfalls of the mainstream educational system (Hasan 2009), which has led to student absenteeism, adjustment problems in the classroom, low student self-esteem and lack of confidence (Mohamad Johdi and Abdul Razak 2009; Mohd Roslan 2016b). In addition, problems have arisen with teachers who were not pedagogically competent and lack the ability to work with indigenous children (Sharifah et al. 2011). The result is that indigenous students lose interest in education, leading to abnormally high dropout rates.

Similarly in Australia, from the 1960s until the present day, the educational policy implemented by various coalition and Labour governments to address inequality in Aboriginal communities, and planning policies have intended to provide the best education possible to indigenous peoples. However, the curriculum was developed and modelled on a mainstream curriculum without considering Aboriginal cultural perspectives, which aggravates certain issues in Aboriginal education. This research explores the level of inclusion of these cultural issues in educational processes and the inclusion of culturally appropriate methods of communication to enhance the transmission of knowledge. If this is fulfilled, it would be in accordance with the action plan, which implements the UNESCO Universal Declaration on Cultural Diversity 2001 (King and Schielmann 2004).

Furthermore, in both Malaysia and Australia, the integration of minority groups into the mainstream curriculum is based on policies created by what governments identify to be "the best education" for indigenous peoples, which can also be interpreted as a form of assimilation. However, despite all efforts and policies to increase education levels among indigenous peoples, studies show these efforts do not provide the best form of education for indigenous students (Brennan 1998; Hasan 2009; Hasmah 2013; McConaghy 2000; Mohd Roslan 2014; Partington and Beresford 2012; Ramle et al. 2013; Sidwell and Roger 2011; SUHAKAM 2012a). The education of indigenous peoples still lags far behind mainstream society (Buckskin 2009; Gale 2000; Hasan 2009; Mohd Roslan and Mansor, 2019). Tom Calma, the Aboriginal and Torres Straits Islander Social Justice Commissioner and National Race Discrimination Commissioner for the Human Rights and Equal Opportunity Commission (HREOC), states that in Australia:

The disparities between outcomes for indigenous and non-indigenous Australians in relation to all areas of the education system are documented and well known. And the statistics are not improving anywhere near the rate that they should be. Many indigenous children are fundamentally disengaged from education. (Calma, 2008 cited in Partington and Beresford 2012, 36) 
Over a period of almost 60 years, the educational disadvantages and issues for indigenous groups in both aforementioned countries regarding mainstream education have not been resolved. The mainstream education for indigenous peoples has not addressed the unique disadvantages indigenous populations face. This lack of progress raises an important question of whether the existing education policy is more beneficial to mainstream society rather than to indigenous communities. Indigenous peoples are alarmingly still disadvantaged in terms of educational achievements, despite a substantial allocation of resources for their education. They are still being serviced through the paradigms of mainstream pedagogy, curricula and syllabi that are discordant with the realities and aspirations of the indigenous groups.

\section{Theoretical Perspective}

This study adopts Foucault's $(1980 ; 1991)$ notion on power, knowledge and normalisation in explaining and understanding the issues in indigenous education policy in Malaysia and Australia. Moreover, the United Nations Declaration on the Rights of Indigenous Peoples (UNDRIP) is an international law that seeks to represent and protect indigenous rights. It has provided several guidelines, such as self-determination as well as rights and equity, which are deemed to be the entitlement and rights of these indigenous groups. The UNDRIP should not be merely a symbolic gesture of acceptance; it has to be a more active and meaningful "recognition of rights". Furthermore, the self-determination rights of indigenous peoples as defined by UNDRIP consist of three-dimensional approaches, which are: (1) the political dimension, which are the rights to autonomy and participation in the decision-making process; (2) the resource dimension, which are the rights to freely dispose of their natural resources; and (3) the external/international dimension, which is the right to protect their collective integrity (Cambou 2019).

Furthermore, the analysis of Foucault's theory can provide a clear understanding of how the educational institution and the government in regulating and shaping the system of education to specific groups, such as indigenous peoples, can be rendered more effective and serve desired outcomes. Foucault in his work argues that 'the rationalities underpinning professionalism are really 'political tactics' and constitute a 'specific way of knowing' which legitimates the normalisation of bodies" (Holligan 1999, 138). His argument reflects a concept that generates a sense of disillusionment within the teaching profession. This refers to the "role played by an educator" (Holligan 1999, 147). His analysis portrays schools as an example and governing the teachers and students as "one way of disrupting the universalist assumptions that reify an exclusive notion of a 'good citizen" 
(Foucault 1979, 136). Such an interpretation can be deployed in Malaysia and Australia in managing indigenous education policies in order to produce good citizens.

Furthermore, Foucault has presented a comprehensive framework and philosophy and prepared illustrations and evidence, which can be practised and applied to the educational systems in Malaysia and Australia. His findings serve as valuable guidance and can identify the best ways to regulate and counter the negative aspects of normalisation. One of his arguments was to modify the negative impact of normalisation in the education system to ensure that student equality and student achievement can be successfully achieved. Thus, he emphasises that "many acts of power and knowledge can interfere with our ability to freely explore how we may live within truth, rather than inside a prison made from our own culture and society" (Quoted in Jardine 2005, 11). Therefore, there exist noteworthy connections between social constructions and normalisation discourses.

\section{METHODOLOGY}

This case study research aims to investigate to what extent indigenous peoples' right to self-determination is expressed in the formulation and development of indigenous education policy, which involves 24 informants consisting of 12 Malaysians and 12 Australians. In-depth interviews were conducted with seven informants (four Malaysians and three Australians), who worked as influential policy makers (e.g., ministers or officers from the Ministry of Education and institutions or department-related to Orang Asli [Malaysia] as well as Aboriginal and Torres Strait Islander people from Australia). Additionally, we included the views of six Malaysian and seven Australian academics who were either university professors or lecturers, as well as schoolteachers and indigenous peoples. We examined their involvement in the formulation of education policy. Four NGOs and expert educational bodies, consisting of two Malaysians and two Australians, related to Orang Asli (Malaysia) and Aboriginal and Torres Strait Islander people (Australia) were involved in this study to make it balanced and comprehensive. This selection of informants was done by purposive sampling and comprised those directly involved in the formulation of educational policy in Malaysia and Australia. The interviews with the three respondent groups (policy makers, academics and NGOs) were analysed using the thematic analysis method. This method was chosen because it allows a determination of emerging categories based on research objectives (Braun and Clarke 2006, 78). Based on ethical considerations, however, all names used in this article are pseudonyms, in order to protect the respondents' identity. ${ }^{5}$ 
This study has notable strengths. First, this research focuses on how governments enact policies to enhance equality for indigenous peoples through education as well as the participation and raising of the level of self-determination of indigenous peoples in education. Second, the informants in this study were people who were directly involved in the formulation of educational policy in Malaysia and Australia, such as ministers, policy makers, educational academics, schoolteachers, NGOs, and expert educational organisations. However, some limitations also warrant mention. Firstly, full self-determination from the government is complex, which involves both equity and recognition of the indigenous community in formal and informal policy making. This requires an analysis of specific programmes, policies and relevant institutions, which have not been explored in the present study. Therefore, we recommend future studies to make a comprehensive evaluation programme that includes analyses on the impact of relevant programmes on the community. Secondly, most of our informants were educated indigenous peoples who were actively involved in the policy-making process. However, we believe the participation of Orang Asli and indigenous peoples' communities from different backgrounds and levels of education as informants is crucially needed to assure a good representation of indigenous peoples in the education policy or system. Future researchers should take this into consideration.

\section{RESULTS AND DISCUSSION}

Self-determination and rights are the major issues raised in the interviews. Self-determination is a principle whereby indigenous peoples are actively involved in the formation of education policy. Articles 3, 4 and 14 of UNDRIP clearly outline the right to self-determination for indigenous peoples. Here are some relevant extracts from UNDRIP:

Article 3: Indigenous peoples have the right to self-determination. By virtue of that right they freely determine their political status and freely pursue their economic, social and cultural development (UNDRIP 2007, 4).

Article 4: Indigenous peoples, in exercising their right to selfdetermination, have the right to autonomy or self-government in matters relating to their internal and local affairs, as well as ways and means for financing their autonomous functions (UNDRIP 2007, 4-5). 
Article 14(1): Indigenous peoples have the right to establish and control their educational systems and institutions providing education in their own languages, in a manner appropriate to their cultural methods of teaching and learning (UNDRIP 2007, 7).

Therefore, it is patently clear that UNDRIP indicates that indigenous peoples should have this encouragement for them to succeed within their country's socioeconomic development simultaneously with the mainstream population. These articles recognise the indigenous rights pertaining to self-determination with regard to education, political affiliation, in addition to economic and cultural aspects.

\section{Representation of Orang Asli in Malaysian Education Policymaking}

In Malaysia, scant emphasis is placed on the self-determination and rights of indigenous groups. Politicians and bureaucrats dominate in the formulation of indigenous education policy and act as mediators to voice opinions on behalf of the community (see Ramlah 2009; SUHAKAM 2010; 2011; 2012b). The responses from interviews demonstrate that policy formation mainly involves individuals from the government. One senior administrator, Ahmad, explained that Jabatan Kemajuan Orang Asli (JAKOA) is a body that is appointed by the government to represent Orang Asli and determine suitable policies for them:

JAKOA is a government body responsible for conveying views on the representation of the Orang Asli on certain issues and escalating the issues for discussion at a higher level of authority. An example would be issues related to the education of the Orang Asli. Even though education is under the Ministry of Education, issues related to education are proposed and advised by JAKOA to the Ministry of Education.

The tok batin (headman) plays significant roles on matters involving culture and customs in their communities. However, JAKOA represents the Orang Asli in Malaysia, with their main function to administrate for protection, welfare, well-being and advancement of the Orang Asli. Ahmad's statement is indicative that as a government body, JAKOA will uphold aspirations that are deemed appropriate by the government. The above statement demonstrates the Orang Asli do not have the power to determine their own direction because it is controlled by an overseeing government body, which has become the mediator between the Orang Asli and the authorities. Based on self-determination rights advocated by UNDRIP and the Malaysian government, it is evident the Orang Asli seem to have some semblance of control. But they lack rights to autonomy or self-government in matters relating to their internal and local affairs. 
However, a senior academic, Hashim, stressed the position of a senator who looks after the welfare of the Orang Asli in Malaysia:

In the Dewan Negara (Senate), we have a senator who is an Orang Asli and represents views regarding Orang Asli affairs. For example, the Senator can advise the Ministry on a better education system for the Orang Asli.

From these statements, it is evident the inclusion of self-determination in the development of indigenous education policy is limited to the direct appointment of a senator to represent the Orang Asli. The Federal Constitution of Malaysia allocates the appointment of a senator by the Yang di-Pertuan Agong (the King) to represent the Orang Asli, but this is considered insufficient. Apart from the appointment of only one senator from the Orang Asli and the portfolios held, there is not one viable agency that is responsible for Orang Asli welfare and considers issues from their unique perspectives. ${ }^{6}$ Therefore, the sole indigenous senator cannot be expected to be effective and have enough authority to represent the Orang Asli in policymaking. In addition, in the Malaysian parliamentary system, the position and role of a senator is only effective within the senate and has limited influence in the process of policymaking. Decision makers are not from the senate. Thus, the Orang Asli are not well represented within the parliament. Furthermore, it needs to be noted that the Orang Asli are not a homogenous group; they comprise various tribes and thus a more representative and meaningful mechanism needs to be put in place.

The appointment of a Malaysian Senator is usually random from those actively involved in society and welfare activities. Although a senator can advise on education matters, it is the Minister of Education who decides on policy matters. This is evidence that the Orang Asli are not autonomous as far as determining their education is concerned. This is in accordance with Rohaida and Witbrodt (2012) and Subramaniam (2011), who contend the notion that the appointment of a senator representing the Orang Asli is supposedly of someone who has power and influence in policymaking.

Furthermore, the Orang Asli do not have a political party that represents them and participates in policy formulation. UNDRIP mandates that indigenous peoples should be included in the determination of education policy. It also includes the right to indigenous self-determination over culture, language, and indigenous pedagogy, according to Articles 31-36 (UNDRIP 2007, 11-13). Furthermore, UNDRIP elaborates rights to indigenous self-determination, including matters 
relating to internal local affairs, such as culture, identity, education, information, media, housing, employment, social welfare, economic activities, land and resources.

\section{Representation of Aboriginal People in Australian Education Policymaking}

A similar interpretation can be identified in Australia's case. The Australian government, in contrast to Malaysia, includes some indigenous peoples in the formulation of its education policy, although at a minimal level (Ministerial Council for Education Early Childhood Development and Youth Affairs 2010; Ministerial Council on Education Employment Training and Youth Affairs 2006; Yunupingu 1995). However, it is evident and this is limited to be merely a symbolic gesture of self-determination because there are very few representatives of Aboriginal and Torres Strait Islander people in Australia's Parliament. This allows for scant autonomy or self-determination in indigenous education policy. This is illustrated by the comments of one senior Aboriginal academic, Michael:

We have many scholars, academics and teachers among the indigenous peoples out there, but we lack administration officers, ministers and politicians. We do have the Ministry of Aboriginal Affairs, but it is led and staffed by non-indigenous peoples. Hence, it is difficult for our voices to be heard. Yes, we do have someone who is in a higher-level position in the department, but this is not a veto and cannot convey and realise our needs and standpoint.

Michael's statement indicates that policymaking in Australia involves people with a higher level of authority from the Department of Aboriginal Affairs and the Department of Education and Training. However, insufficiently few representatives from the indigenous community are involved in the decisionmaking process. While there exist avenues for the indigenous to air their opinions, the critical power to ensure these do get translated into actual practical realities is not agreeable. This is clear evidence the voices of indigenous peoples are not heard adequately enough for the government to be able to fully address them in accordance with UNDRIP Article 32(2), (UNDRIP 2007, 12):

States shall consult and cooperate in good faith with the indigenous peoples concerned through their own representative institutions in order to obtain their free and informed consent prior to the approval of any project affecting their lands or territories and other resources, particularly in connection with the development. 
The decision-making process involves many indigenous and non-indigenous individuals who have strong academic backgrounds and experience in policymaking. However, the final decision to implement and continue the current policy is being undertaken by the minister. One senior administrator, Adrian confirmed that:

The Minister for Indigenous Affairs in the Department of the Prime Minister and Cabinet covers all Indigenous Affairs policies and programmes which are responsible for indigenous education, improving school attendance and education outcomes, improving community safety, etc.

Adrian's statement is evidence that the minister has the power to determine policy for the development of Aboriginal people. In the extract below, Michael explained that most of the people who are involved in decision making for Aboriginal people are bureaucrats, who are mostly non-indigenous peoples. He claimed that:

We can see who are involved in the development of policymaking process... Most of them are elitists...even though some of them are Aboriginal and Torres Strait Islander people like [name excluded] and [name excluded]. However, the non-indigenous peoples are still in control in terms of the financial provision and administration of the development of Aboriginal people's education in Australia. Most people who are involved have positions in the organisation, strong background in terms of academic and experience concerning education...involvement is just for the sake of formulation but not in the final decision-making.

This is further evidence that symbolic self-determination is being practised. Orang Asli, as well as Aboriginal and Torres Strait Islander people are not prominent in their respective governments and are excluded as far as the development of policy is concerned. They have no political parties to represent them in policymaking, resulting in less autonomy over their own interests and governance. The indigenous peoples of Malaysia and Australia are consequently disadvantaged. Daes argues that what is needed is for "the state to share power democratically under a constitutional formula and to guarantee effective representatives" (Daes 1996, 256). However, the Orang Asli and Aboriginal people are still under the governance and control of the dominant political systems and lack political parties to represent them (Beresford and Gray 2012; Gray and Partington 2012; Mohd Roslan 2016b; Mohd Roslan, Mansor and Nik Alia Fahada 2019; Partington and Beresford 2012). Therefore, it can be argued that the governments in both countries, in effect, shape the indigenous peoples according to their own needs. 


\title{
Financing and Funding in Indigenous Peoples' Education
}

Foucault (1988) distinguishes between social relations and political apparatuses. According to him, power is enforced by the law and is centralised in and originates from the Federal Constitution. For instance, the allocation of financial assistance by Malaysia is handled by government ministries and not by the Orang Asli in any way, shape or form.

Symbolic self-determination and indigenous rights are also reflected in the funding allocated to indigenous peoples. While financial provision for Orang Asli education increases every year, the administration of these finances is still controlled and administered by JAKOA. ${ }^{7}$ JAKOA senior administrator, Kamal, stated that:

\begin{abstract}
We are responsible for planning and distributing the allocation granted by the government. We make a proposal to the government every year and, through the approved allocation from the government, we prepare a programme for the Orang Asli community, including educational programmes.
\end{abstract}

This response demonstrates that rights to self-determination are still under the control of JAKOA, which is responsible for preparing the budget and financial plan to make an annual allocation to the Orang Asli. However, the process of preparing the budget and financial plan involves only policymakers and is not discussed with the Orang Asli. This was further confirmed by an Orang Asli senior academic, Rosli:

There are improvements in the financial provision for the Orang Asli educational programme every year. But the administration is handled and determined by the JAKOA. The Orang Asli are not involved with the programme, but they also have no knowledge of issues of concern.

According to Rosli, there is monetary allocation provided by the government to develop the Orang Asli. Even though this allocation or budget has been increasing every year, the government does not fulfil the needs or demands of the Orang Asli. The budgeting for the Orang Asli does not represent equal development for them. UNDRIP stresses the rights of self-determination, especially autonomy or self-government relating to internal and local affairs. This includes financing indigenous autonomous functions and establishing and controlling their educational systems and institutions to provide education in their own languages, in a manner appropriate to their cultural methods of teaching and learning. 
This analysis demonstrates that funds are equitable, but what is important is how the funds are used and whether they benefit the Orang Asli.

Similarly, the allocation of money in Australia is controlled by the department and by certain political parties. Aboriginal participation in the implementation of policy is limited. An educator, Maria, explained that non-Aboriginal people are still controlling the financial provision and administration in the development of Aboriginal people's education in Australia.

This highlights that finances for the development of educational policy in Australia is still under control of non-Aboriginal people. The tension arising between the demands of the providers who fund indigenous education and the indigenous peoples themselves was a central issue for many educators. Aboriginal people claim they should have self-determination and full autonomy in determining how the allocation provided for their education system is implemented.

Another respondent, Dayton who is a senior Aboriginal academic believed that the issue of standards was a question about who controls indigenous education. Full autonomy and control are not only about funding, but also about the curriculum. He says:

Even though Aboriginal people are involved in terms of the implementation process, they should also be given a chance to manage and handle their own education system, not only in terms of the curriculum, but also in the management of funding. This is to ensure that their education system is siding with them.

This indicates that an emphasis on the right to control indigenous education funding can be offered as a viable alternative within indigenous educational institutions. However, this depends upon the implementation of collective power between indigenous peoples and the government. This involves the allocation of resources and finances for the development of curriculum, along with the flexibility to incorporate Aboriginal and Torres Strait Islander staff within educational institutions.

Therefore, the negotiation of power between Aboriginal people and the government is vital to ensure that the allocation for Aboriginal education achieves the targeted goals. UNDRIP states that indigenous peoples have the right to autonomy or self-government in matters relating to their internal and local affairs, as well as to the means to finance their autonomous functions to ensure they can control their educational system and institutions. Thus, regulation is 
important to ensure that Aboriginal education programmes receive an adequate allocation. Michael makes a similar argument that financial provision is fully controlled by the government. The government has the power to reduce the allocation and terminate policies. For example, bilingual education was terminated by the government due to a budget reduction in education, even though the programme achieved positive outcomes. He stated, "When the government decides to decrease the financial budget, hence the (bilingual education) programme must come to a halt. Even though bilingual education received a good positive outcome".

Thus, both countries grant only limited autonomy over funding management. It is managed by JAKOA and education institutions in Malaysia, and by the Aboriginal Affairs Department in Australia. Therefore, both nations restrict the application of Article 4 of UNDRIP, which highlights the need for economic autonomy in education funding, "... as well as ways and means for financing their autonomous functions" (UNDRIP 2007, 4). The interviews illustrate how the Orang Asli as well as the Aboriginal and Torres Strait Islander people are not in a position of power or autonomy within their respective countries. They are denied full and equal participation in the political processes, which affects the formulation of certain policies, especially in the education system. They also do not have political parties to support their agendas and advocate for self-determination.

Hence, the implementation of education policy is still controlled by the government. For example, there is limited financial provision in policymaking. Therefore, absolute rights to self-determination through the guidelines outlined by Articles 3, 4 and 14 of UNDRIP are limited. The current self-determination of the Orang Asli and Aboriginal people is contrary to Anaya's $(2004,150)$ view of self-determination, which is "administrative autonomy by indigenous peoples". Currently, clear limits are placed on the level of self-determination in education policy. The structure of the education system is regulated by non-indigenous peoples. Articles 14 and 15 of UNDRIP address the rights of indigenous education (UNDRIP 2007, 7):

Article 14(1) - Indigenous peoples have the right to establish and control their educational systems and institutions providing education in their own languages, in a manner appropriate to their cultural methods of teaching and learning; and

Article 15(1) - Indigenous peoples have the right to the dignity and diversity of their cultures, traditions, histories and aspirations which shall be appropriately reflected in education and public information. 
Another issue that was raised was that indigenous peoples have no representation regarding participation. There are no indigenous representatives who can represent and speak on behalf of indigenous peoples. There were strong convictions on both sides of the debate about indigenous control over curriculum content and educational institutions overall. The need for representation from the Orang Asli as well as Aboriginal and Torres Strait Islander people, which could lead to indigenous self-determination, will be discussed next.

\section{Orang Asli in Participation as Choices of Governance}

Another reason why self-determination in both nations is limited to token symbolism is a political factor, namely representation in policymaking. ${ }^{8}$ Representation is important for indigenous peoples because it results in selfdetermination. However, in Malaysia, the number of educated Orang Asli who have expertise in the formulation of education policy is limited. This poses a debilitating barrier to the involvement of the Orang Asli in decision-making at various levels of indigenous education policy.

Most viewpoints and critiques about government education policies are propounded by non-indigenous individuals. This clearly demonstrates there is either a lack of participation of the Orang Asli in decision-making or they are not given sufficient opportunity. This is highlighted by JAKOA senior administrator, Siti:

The Orang Asli communities are still left behind and the level of education is being decreased. So, how are they going to get themselves involved with matters affecting policy making? Even though they have knowledge regarding their own language, culture etc., they do not have the expertise in the curriculum system and administration.

This is reflective of the Orang Asli's limited knowledge regarding the management, administration, and delivery of teaching within the education system. This contrasts with UNDRIP's aim that “indigenous peoples have the right to establish and control their educational systems and institutions providing education in their own languages, in a manner appropriate to their cultural methods of teaching and learning" (UNDRIP 2007, 7). Even though they have limited knowledge regarding the education system, they can be granted opportunities to have input on their knowledge pertaining to culture and language to be included in the curriculum. The government should develop policies and curricula by incorporating indigenous expertise and perspectives about educational content rather than imposing comprehensive systems that operate in mainstream realms. 
Some interview responses indicated there is a need to facilitate self-determination, especially regarding community needs and development. Hashim emphasises the Orang Asli have a very minimal voice in the development of the education system:

The voice of the Orang Asli is very minimal. They do not have the strength to voice their views, especially on the education system. This is because of the lack of educated people among them, which then presents problems in determining the matters concerning the implementation of a policy.

The above interview response demonstrates that there are barriers to the voice of the Orang Asli in the education system. This is because they are not present in the organisation or front line of the education system. Therefore, they are not heard by the state, and there is a lack of educated people to influence the existing education system in Malaysia. Based on this analysis, it is our contention to argue that it is important to include the aspirations and knowledge of the Orang Asli in the indigenous curriculum to assure their participation in education. This would not only accelerate the learning process, but also recognise and consider their unique situation, talents, sensitivities as well as limitations.

Thus, based on the right to self-determination, we argue that more Orang Asli should be given the fullest support possible to become teachers or academics such that they can develop expertise in education to design an optimal curriculum that is based on their culture, identity, language and indigenous knowledge. Based on the report of the Department of Orang Asli Affairs $(2008,58)$, a total of 170 Orang Asli are teachers in Malaysia. This number is woefully small when compared with the total number of teachers in Malaysia, with a count of 413,374 total teachers (Jabatan Perangkaan Malaysia 2016). Consequently, new Orang Asli educators can be advocates in the education system, based on the aspirations stated in UNDRIP Article 13 (UNDRIP 2007, 7):

Indigenous peoples have the right to revitalise, use, develop and transmit to future generations their histories, languages, oral traditions, philosophies, writing systems and literatures, and to designate and retain their own names for communities, places and persons.

\section{Aboriginal People in Participation as Choices of Governance}

The situation varies somewhat in Australia. There are Aboriginal and Torres Strait Islander people who have expertise and knowledge about their people and how the curriculum relates to them. This was highlighted by Michael: 
In Australia today, there are 6,000 [indigenous] people qualified to teach. It is not a big number, but 6,000 is 6,000 . There are 75 of those people who are school principals. Therefore, they know the stuff really well. There are other people out there with doctorate qualifications.

Aboriginal people are involved in the education sector, however, the increasing number of educators among Aboriginal people does not necessarily represent an increase in the voices and aspirations of their community. Thus, it is questionable whether they are heard or listened to by the government; or if the education system is based on indigenous voices and aspirations. The increasing number of educators does not guarantee that the voices of Aboriginal people will be heard in the education system. Rigney stated that in 2004 , only $0.7 \%$ of all teachers in Australia were indigenous (Rigney 2007, 24). This is insignificant compared to the 168,803 Aboriginal and Torres Strait Islander students attending school in Australia in 2011. A total of 143,839 (85.2\%) attended government schools, 16,098 (9.5\%) attended Catholic schools and 8,866 (5.3\%) attended independent schools (Australian Bureau of Statistics 2012).

However, the voice, aspirations, rights and demands of Aboriginal people in the education system are still denied. Maria stressed this issue, stating that having more indigenous teachers is a key factor in fostering student engagement and improving educational outcomes for indigenous and non-indigenous students:

There are many scholars, academics and teachers among the Aboriginal and Torres Strait Islander people out there. Even though they are involved in terms of the implementation, they should also be given chances to govern and manage their own education system, not only in terms of curriculum but also in funding management, which need to be controlled by themselves to ensure the education system is really on their side.

Maria's statement illustrates that Aboriginal people have a clear understanding concerning their demands on the education system. Their aspirations and needs would be met by recognising the language, indigenous knowledge, and culture in the education system. However, the views of non-Aboriginal people in education continues to dominate and there is a significant disadvantage in how indigenous peoples participate in educational institutions. Generally, Aboriginal and Torres Strait Islander students receive an education that does not represent their aspirations or align with their worldview. The emphasis on their right to self-determination is dominant among the respondents and is most pervasive within the educational institutions involved. Indeed, there are instances where Aboriginal and Torres Strait Islander educators are agents of assimilation because they lack the options to evaluate and control the curriculum. 
The number of indigenous teachers and educators in the education systems in both countries does not indicate effective participation by indigenous peoples in those systems. For example, the Australian government does not offer adequate opportunity for Aboriginal people to determine a suitable model for their education and the direction they desire to proceed in designing their own future. Therefore, opportunity, space for involvement and encouragement from the government are the best indicators of enhanced rights to self-determination. According to Articles 14 and 15 of UNDRIP, indigenous peoples should have self-determination and rights to establish control in the education system based on their cultural, linguistics and spiritual knowledge.

\section{The Impact of Non-Indigenous Peoples as Malaysian Educational Policymakers}

The autonomy and rights to self-determination for indigenous peoples are not given prominence in educational policy. For example, in Malaysia there is a shortage of educated people among the Orang Asli, which results in an inability to negotiate their education policy. This is another example of mere symbolic self-determination and rights practised in Malaysia. The Orang Asli are merely the recipients of policy and their opinions are not advanced to higher levels of authority. Another contributing factor to this situation is that JAKOA acts on behalf of the Orang Asli as their spokesperson, which is often at variance with the actual aspirations and desires of the Orang Asli. One NGO respondent, Rozita, who is a representative of Orang Asli explained that:

The one who fights for our rights in education is not one of us. In determining a policy, it is impossible to implement what we want. As an NGO, which represents Orang Asli, we could just provide our views and opinions. But the decisions are in the hands of higher authorities whether to accept or decline our views. Unfortunately, I do not see that our views are accepted by the government.

A similar argument was advanced by a senior academic, Salleh, who felt that the low number of policymakers and educated people among the Orang Asli has made it difficult to determine a proper education policy. The Orang Asli are unable to effectively advance their views and opinions to ensure the education system is favourable to them. Salleh argued:

If we look at the people who are in the JAKOA and the Ministry of Education, none of them are Orang Asli. These organisations are governed by non-indigenous peoples. This has resulted in the minimal influence of the opinions of the Orang Asli. There are Orang Asli who 
work in the department but only as clerks or in other lower positions. Even teachers...how many of them are Orang Asli? Very few of them. Therefore, how can issues concerning education be highlighted?

This indicates there is a lack of substantive participation towards selfdetermination and the rights of indigenous education policy. Because the state encourages their involvement, it requires representatives from the Orang Asli to advocate for their needs and aspirations in education. According to Rohaida (2010, 18), rights in Malaysia - especially for Orang Asli-depend on internal factors and not on international designation or implementation. To achieve this, Articles 2 to 4 of UNDRIP (the recognition of the rights of indigenous peoples), Articles 14 and 15 (specific rights in education policy), and Articles 31 to 35 (rights to indigenous self-determination, including matters relating to internal local affairs such as culture, identity and education) should be fully implemented and these rights given to Malaysia's Orang Asli.

\section{The Involvement of Indigenous Peoples in Australian Education Policymaking}

In Australia, Aboriginal and Torres Strait Islander academics are actively involved in the development of indigenous education policy. This was confirmed by a senior Aboriginal administrator, Adam:

In indigenous education policymaking, we do get scholars from the Aboriginal people to get involved and give us input about what they want in the education system and all...for example, we appointed [name excluded] to lead a task force. This task force involves scholars and NGOs from the Aboriginal people.

Adam expressed the present state of indigenous participation in developing and formulating indigenous education. Even though there is currently participation among Aboriginal people in the education system, the extent of their function and their ability to improve indigenous education is unclear. Indigenous education remains in a state of dependence on mainstream society, as argued by Brenda:

Participation in formation of a policy is not just a mere involve(ment) for verification but it needs to be more than that especially in terms of providing focus to the content of a policy.... We can see the education system for Aboriginal people still depends on the mainstream education.

This statement portrays indigenous education as being dependent and influenced by mainstream education. Aboriginal participation should encompass all aspects 
of the management, administration, and delivery of curriculum in the education system. This aligns with the UNDRIP requirement that indigenous peoples should control their educational systems. Aboriginal people do participate in the evaluation process by giving feedback on indigenous education policy, as evidenced by Michael's response. However, the bigger question is to what extent their voice is heard and given weight in determining the educational system. As Michael says, "Yup, we are involved in the evaluation process, we give feedback on indigenous education policy, the problems, benefits, advantages and all. But the most important is how far the opinion can be accepted".

The concern is how far the ideas, aspirations and knowledge delivered to policymakers are considered relevant. This is because participation is a fundamental principle for ensuring the educational demands of indigenous peoples are heard and met. The participation of indigenous peoples in all stages of the design, implementation and evaluation of educational programmes is vital to their success. The importance of indigenous participation at the different levels of decision-making can be seen as resulting from the government's shift from central authority to a decentralisation of power to the community. Therefore, it is important that Aboriginal and Torres Strait Islander people actively seek increased participation at every level of education. This would ensure an effective outcome in indigenous education policy.

This argument was further supported by the few respondents who are Aboriginal academics. Respondent Dayton stressed that it is essential to have Aboriginal representatives amongst policymakers, as well as support staff, such as teachers to administer and deliver educational programmes for Aboriginal and Torres Strait Islander students. He stated:

Those who are involved in education at every level, including teachers, teachers' assistants, support staff and administrators, need to be Aboriginal and Torres Strait Islander people. Even if they're not, there should be cooperation between indigenous and non-indigenous peoples. This is to ensure that all individuals continue to make an effort to integrate and enhance the culture of Aboriginal and Torres Strait Islander people... Aboriginal people need to participate and engage together with the key stakeholders to ensure the best educational outcomes in indigenous education policy. 
A similar point is highlighted by Brenda, a senior Aboriginal academic, who felt that all individuals in various levels of education need to cooperate in administering and delivering educational programmes:

In indigenous education policy, we acknowledge the Aboriginal and Torres Strait Islander people as representatives determined by their own associations and independent bodies...like...cooperation with government sectors and negotiation over the implementation of strategies under the principles of self-determination, social justice and reconciliation... These elements have become the basis for the formation of policy... How far can this be executed anyway? I mean, yes, there are teachers among the Aboriginal people, teacher's assistants, academics etc. However, we need to have adequate levels of participation amongst them to ensure the needs, interest and well-being of Aboriginal people, which can also bridge the gaps between schools and the community as well as with the key stakeholders. This vision can be achieved only if their participation in the education system is taken into account, because they understand the culture and the social life of Aboriginal and Torres Strait Islander people better than anyone else.

Both statements clearly highlight the importance of Aboriginal and Torres Strait Islander participation in the education system. "Participation", including as a teacher is a manifestation of "self-determination" and "rights" through representatives who determine the aims of the education of Aboriginal and Torres Strait Islander people in Australia. Educational outcomes will improve the educational performance of indigenous students. Hence, participation and cooperation between the key stakeholders and Aboriginal people are important, especially in the implementation phase. This achieves balance and control in the education system such that it can benefit Aboriginal and Torres Strait Islander students and indirectly empower the community through "participation" in education. This finding is consistent with Cain (2015), Hyde, Carpenter and Conway (2014), as well as Partington and Beresford (2012) who all hold that community involvement is important for the success of indigenous education policy outcomes.

Participation is the main indicator of rights of self-determination within indigenous education. This is also related to citizenship rights. In many nations, the levels of equality and participation in indigenous education are the main indicators of this concept. The rights to self-determination focus on the control, access and participation in the indigenous educational system by those groups identified as disadvantaged. As reflected from the interview data, there were three main aspects to indigenous participation: first, full autonomy or self-government 
in matters relating to their internal and local affairs in terms of control of the education system; second, more indigenous representation in the education system and political structure; and third, the right to provide education in their own languages.

\section{Normalisation in the Malaysian and Australian Education Systems}

Normalisation is a complex process and it requires efforts from the governments in seeking to improve the quality of life of indigenous peoples. However, it can also limit the level of their self-determination. The challenges in both Malaysia and Australia include such aims of indigenous peoples like identity recognition, land ownership, and an acknowledgement of the importance of embedding linguistic, cultural and also spiritual aspects in their education system (Gray and Partington 2012; Harris 2012; Kanu 2007; Leonie et al. 2015; Ramle et al. 2013; Rigney 2010; Rumsey 2012; Wan Zawawi 1996). However, both governments historically used assimilation and nation-building, among other mainstreaming tools in order to develop indigenous peoples' lives. The normalisation process challenges self-determination and still does not achieve satisfactory educational outcomes.

Tracking from the early days until 2015, the policy of the Malaysian government's movement on improving indigenous peoples, it can be argued that it is a complex situation between the state and the indigenous peoples in improving the indigenous education system. Although the discourses are circulated from the top-down through sovereign power, the degree of the normalisation process is still not yet achievable. It is not an easy course, and requires much structural work, especially closed networking between the state and indigenous peoples without involving any third parties, such as NGOs or any state representatives' institutions. Quoting Foucault's work, Britzman (1998), suggests there is a connection between social constructions of race and normalising discourses. Britzman (1998, 110-111) highlights, "how the 'normal' version of multi-races pedagogy (i.e., multicultural education) relies on humanistic constructs or role models and self-esteem building and seems to forget the problem of group identification and disassociation from the question/possibility of difference in line with normalizing." Britzman suggests that if we accept efforts at multi-race pedagogy, we enact as such through bilingual education, indigenous knowledge, and culture, as being "embedded within complex social constructions of race, difference, and normalcy, then we should engage with what it excludes" (Britzman 1998, 111). 
In regard to the situation found in Australia, from 2007 until the present day, the Australian government states that the main aim of the education system for Aboriginal students is to "close the gap" in disadvantages such that they are not left behind. These initiatives were the result of the power and authority held by the state. The state played a significant role in acknowledging the rights and equality of Aboriginal people in education in line with UNDRIP. This led to the process of normalisation. Minson $(1986,145)$ suggests that, "the challenge of power and normalisation over social organisation, thought, and action implies a social revolution, the transformation of one society into another, a truly social one."

\section{CONCLUSION}

It can be concluded that in Australia, although they are not represented on the political level, there are Aboriginal representatives like teachers and academics who can convey opinions to influence the education system. Many would nonetheless argue there is no full self-determination because bilingual education was abolished. However, in Malaysia, the Orang Asli have very limited rights to self-determination in indigenous education policy. This is because they lack representation at every level of policymaking, which prevents them from presenting and delivering their views in the determination of indigenous education policy. Australia's Aboriginal and Torres Strait Islander people are more actively involved in their education system because they have representatives in the policymaking process, as suggested by Anaya (2004).

From the above discussion, we can observe how both states govern indigenous peoples throughout the development process and the formulation of education policies. Foucault's argument of governmentality and governance relates to how the government desires to manage and shape the people according to their demands. It can be argued that the Malaysian government does not take a sufficient account of the Orang Asli in the formulation of education policies. It is possible that it apparently does this such that it can be perceived as fulfilling the UNDRIP aims of looking after the indigenous population. However, the governments in Malaysia and Australia still prioritise the assimilation of their indigenous populations with the mainstream in national development. In both nations, the concept of the negotiation between government and indigenous peoples is imprecise. The conflict in Malaysia has not only been provoked by the limited amount of people that are involved in effective decision-making, but also by difficulties in determining suitable policies by these people. The success of many indigenous peoples in Australia aids the development of the community 
but has limited political representation to promote the aspirations and demands of indigenous peoples, which is a significant barrier. Malaysia attempts to fulfil the indigenous community's demands, but only considers them as one ethnic community among many in the country, while Australia's aim is the national interest.

\section{ACKNOWLEDGEMENTS}

The authors would like to thank the following: JAKOA and University of South Australia for technical support and advice especially, Associate Professor Dr. Peter Gale, University of South Australia; Universiti Putra Malaysia and Kementerian Pendidikan Malaysia (Skim Latihan Akademik IPTA/ BUMIPUTERA [SLAI/SLAB] - KPT(BS)22.12.2011) for the financial support and those involved in this research. The authors would like to thank Dr. Marcus B. Griffin, Founding Editor, American Proofreading Center for English editing of the manuscript. Some of the contents in this article were excerpted from various chapters of Mohd Roslan Rosnon's PhD thesis.

\section{NOTES}

1. The factors that affect indigenous outcomes are the participation of indigenous peoples in decision-making (Hasan 2009; King and Schielmann 2004; Rohaida and Witbrodt 2012; Subramaniam 2012), design (Partington and Beresford 2012; Sharifah et al. 2011; Hasan 2009; Buckskin 2009; Champagne and Ismael 2006) and implementation (Partington and Beresford 2012; Tay 2009; Mohamad Johdi and Abdul Razak 2009; Dentan, William-Hunt and Edo, 2011) of education programmes.

2. The Orang Asli are the indigenous minority peoples of Peninsular Malaysia. It is a Malay term, which translates as "original peoples" or "first peoples" (Nicholas 2000). Eighteen ethnic subgroups are generally thus classified for official purposes under Negrito, Senoi and Proto-Malay (JAKOA 2011). The other original people in Malaysia are Malays, and an array of Sabah and Sarawak "native peoples" (Hood 2004; Hassan 1998).

3. The Second Malaya Plan (1961-1965) was an economic development plan launched by the government of Malaysia, and involved increased expenditure for the development of agriculture and rural areas, where the objective was "to provide facilities and opportunities for the rural population to improve its level of economic and social well-being" among rural Malays and the Orang Asli.

4. The Tenth Malaysian Plan included the national budget from 2011 to 2015 for all economic sectors in Malaysia. It underlines five strategic objectives to achieve a wealthier nation by 2020 . These objectives are: (i) to increase 
the value of the country's economy; (ii) to improve knowledge abilities and innovation, and inculcate first-world thinking; (iii) to continuously address socioeconomic inequalities; (iv) to improve the quality of life; and (v) to strengthen the country's institutions and the implementation of policies.

5. A pseudonym is a false name to conceal identity.

6. Federal Constitution, Art. 45(2)

7. See the Pelan Strategik Jabatan Kemajuan Orang Asli 2011-2015 (Strategic Plan of Department of Orang Asli Development 2011-2015).

8. Anaya $(2004,150)$ argued that, in the context of indigenous peoples, two distinct but interrelated self-government norms are involved. They are: (i) to uphold spheres of governmental or administrative autonomy to indigenous peoples; and (ii) to engage effective participation of those communities in all decisions affecting them.

\section{REFERENCES}

Ah Sam, M. and C. Ackland. 2005. The curriculum. In Introductory indigenous studies in educations, eds. J. Phillips and J. Lampert, 182-199. Australia: Pearson Education Australia.

Anaya, J.S. 2004. Indigenous peoples in international law. 2nd ed. Oxford: Oxford University Press.

Asnarulkhadi Abu Samah. 2005. Orang Asli: Mainstreaming minority consumers. In Consumers in the development, eds. Nurizan Yahya, Mohd Amin Othman and Sharifah Azizah Harun, 264-276. Serdang: Universiti Putra Malaysia.

Asnarulkhadi Abu Samah, Maria Mansor, Zahid Emby, Mariani Mansor and Hanina Halimatusaadiah Hamsan. 2007. Integrated curriculum for Orang Asli/Penan (KAP): A new approach in community education development among the Orang Asli/Penan. Paper presented at the National Seminar of Social Science: Sains Sosial Teras Pembangunan Modal Insan, Kuala Lumpur.

Australian Bureau of Statistics. 2012. Aboriginal and/or Torres Strait Islanders students. http://www.abs.gov.au/ausstats/abs@.nsf/Previousproducts/4221.0Main $\% 20$ Features 402011 ? opendocument $\&$ tabname $=$ Summary $\&$ prodno $=4221.0$ \&issue $=2011 \&$ num $=\&$ view $=($ accessed 15 September 2015$)$.

Beresford, Q. and J. Gray. 2012. Models of policy development in Aboriginal education. In Reform and resistance in Aboriginal education, eds. Q. Beresford, G. Partington and G. Gower, 120-148. Western Australia: UWA Publishing.

Braun, V. and V. Clarke. 2006. Using thematic analysis in psychology. Qualitative Research in Psychology 3: 77-101. https://doi.org/10.1191/1478088706qp063oa

Brennan, C. 1998. Why isn't it being implemented? Race, racism and indigenous education. In Perspective on Aboriginal and Torres Strait Islander education, ed. G. Partington, 147-170. Katoomba: Social Science Press.

Britzman, D.P. 1998. Lost subjects, contested objects: Toward a psychoanalyfic inquiry of learning. New York: New York University Press. 
Buckskin, P. 2009. Hawke and Ryan: An acceleration of Indigenous education policy. In The Hawke legacy, eds. G. Bloustien, A. Mackinnon and B. Comber, 83-95. Adelaide: Wakefield Press.

Cain, G. 2015. Working with teaching assistant and others support staff for inclusive education. International Perspectives on Inclusive Education 4: 133-151. https://doi.org/10.1108/S1479-363620150000004006

Cambou, D. 2019. The UNDRIP and the legal significance of the right of Indigenous peoples to self-determination: A human rights approach with a multidimensional perspective. The International Journal of Human Rights 23(1-2): 34-50. https://doi.org/10.1080/13642987.2019.1585345

Champagne, D. and Ismael Abu-Saad. 2006. Introduction: Seeking common ground through education. In Indigenous education and empowerment: International perspective, eds. D. Champagne and Ismael Abu-Saad, 1-12. Oxford: AltaMira Press.

Daes, E.I. 1996. The right of indigenous peoples to 'self-determination' in the contemporary world order. In Self-determination: International perspectives, eds. D. Clark and R. Williamson, 47-57. New York: St. Martin's Press. https://doi.org/10.1007/ 978-1-349-24918-3_3

Dentan, R., A. William-Hunt and J. Edo. 2011. They do not like to be confined and told what to do: Scooling Malaysian indigenes. In Everyday Life in Southeast Asia, eds. K.M. Adams and K.A. Gillogly, 283-342. Bloomington: Indiana University Press.

Department of Orang Asli Affairs. 2008. The basic data of Orang Asli. Kuala Lumpur: Department of Planning and Research Orang Asli Affairs.

Foucault, M. 1979. Discipline and punishment: The birth of the prison. London: Penguin Books.

1980. Power/knowledge. Brighton: Harvester.

1988. Politics and reason. In Politics, philosophy, culture, ed. L.D. Krizman, 5785. London: Routledge.

. 1991. Governmentality. In The Foucault effect: Studies in governmentality: with two lectures by and an interview with Michel Foucault, eds. M. Foucault, G. Burchell, C. Gordon and P. Miller, 87-104. Chicago: University of Chicago Press.

Gale, P. 2000. Indigenous rights and higher educations in Australia: Not just black and white. In Local knowledge and wisdom in higher educations, eds. G.R. Teasdale and Z. Ma Rhea, 95-108. London: Emerald Publishing Limited.

Gray, J. and G. Partington. 2012. Attendance and non-attendance at school. In Reform and resistance in Aboriginal education, eds. Q. Beresford, G. Partington and G. Gower, 261-303. Western Australia: UWA Publishing.

Harris, J. 2012. Losing and gaining a language: The story of Kriol in the northern territory. In Language and culture in Aboriginal Australia, eds. M. Walsh and C. Yallop, 5th ed., 145-154. Canberra: Aboriginal Studies Press.

Hasan Mat Nor. 1998. Masyarakat Orang Asli dan Akta 134 (Akta Orang Asli): Kaitannya dengan pembangunan. In Warga pribumi menghadapi cabaran pembangunan, ed. Hassan Mat Nor, 88-120. Selangor: Universiti Kebangsaan Malaysia. 
2009. Cabaran pendidikan Orang Asli di Malaysia. In Masyarakat Orang Asli: Pespektif Pendidikan dan Sosiobudaya, eds. Abdul Razak Ahmad and Zalizan Mohd Jelas, 217-228. Selangor: Universiti Kebangsaan Malaysia.

Hasmah Abdul Manaf. 2013. Hak pendidikan kanak-kanak Orang Asli. Malaysian Journal on Human Rights 7: 56-69.

Holligan, C. 1999. Discipline and normalisation in the nursery: The Foucauldian gaze. Scottish Educational Review 31(2): 137-148.

Hood Salleh. 2004. Dunia peribumi dan alam sekitar: Langkah ke hadapan. Bangi: Universiti Kebangsaan Malaysia.

Hyde, M., L. Carpenter and R. Conway. 2014. Diversity and inclusion in Australian schools. South Melbourne: Oxford University Press.

Jabatan Kemajuan Orang Asli (JAKOA). 2011. Pelan strategik Jabatan Kemajuan Orang Asli 2011-2015. Kuala Lumpur: Kementerian Luar Bandar dan Wilayah.

Jabatan Perangkaan Malaysia. 2016. Malaysian education statistic. Putrajaya: Jabatan Perangkaan Malaysia.

Jardine, G.M. 2005. Foucault and education. New York: Peter Lang Publishing, Inc.

Kanu, Y. 2007. Increasing school success among Aboriginal students: Culturally responsive curriculum or macrostructural variables affecting schooling? Diaspora, Indigenous and Minority Education 1(1): 21-41.

King, L. and S. Schielmann. 2004. The challenge of indigenous education: Practice and perspectives. France: UNESCO Publishing.

Leonie, A., J. Lasimbang, H. Jonas and B. Mansul. 2015. Red and raw indigenous rights in Malaysia and the law. Sabah: Jaringan Orang Asal SeMalaysia.

McConaghy, C. 2000. Rethinking indigenous education: Culturalism, colonialism and the politics of knowing. Flaxton: Post Pressed.

Ministerial Council for Education Early Childhood Development and Youth Affairs. 2010. Aboriginal and Torres Strait Islander education plan 2010-2014. Carlton South Victoria: Ministerial Council for Education, Early Childhood Development and Youth Affairs.

Ministerial Council on Education Employment Training and Youth Affairs. 2006. Australian direction in indigenous education (2005-2008). Carlton South Victoria: Ministerial Council on Education Employment Training and Youth Affairs.

Minson, J. 1986. Strategies for socialists? Foucault's conception of power. In Towards a critique of Foucault, ed. M. Gane, 106-148. London: Routledge.

Mohamad Johdi Salleh and Abdul Razak Ahmad. 2009. Kesedaran pendidikan dalam kalangan masyarakat Orang Asli. In Masyarakat Orang Asli: Perspektif pendidikan dan sosiobudaya, eds. Abdul Razak Ahmad and Zalizan Mohd Jelas, 47-62. Bangi: Universiti Kebangsaan Malaysia.

Mohd Roslan Rosnon. 2014. Challenges on the Orang Asli's rights in mainstream education in Malaysia: An overview. Malaysian Journal on Human Rights 8: $57-72$.

2016a. Indigenous education policies in Malaysia and Australia: A study of the recognition of indigenous rights and self-determination. $\mathrm{PhD}$ diss., University of South Australia, South Australia. 
2016b. Indigenous education policy in Malaysia: A discussion of normalization in schooling. Journal of Education and Social Sciences 4(June): 25-32.

Mohd Roslan Rosnon and Mansor Abu Talib. 2019. Indigenous education rights: The Malaysian case. International Journal of Academic Research in Business and Social Sciences 9(10): 149-167. https://doi.org/10.6007/IJARBSS/v9-i10/6470

Mohd Roslan Rosnon, Mansor Abu Talib and Nik Alia Fahada Wan Abdul Rahman. 2019. Self-determination of indigenous education policies in Australia: The case of the Aboriginal people and Torres Strait Islander people. Pertanika Journal of Social Sciences and Humanities 27(S1): 267-284.

Mohd Roslan Rosnon and S. Chinnasamy. 2015. Discourse of indigenous education policy: The Malaysian case. International Journal for Innovation Education and Research 3(10): 126-140. https://doi.org/10.31686/ijier.vol3.iss10.453

Nicholas, C. 2000. The Orang Asli and the contest for resources: Indigenous politics, development and identity in Peninsular Malaysia. Copenhagen: International Work Group for Indigenous Affairs.

Partington, G. and Q. Beresford. 2012. The context of Aboriginal education. In Reform and resistance in Aboriginal education, eds. Q. Beresford, G. Partington and G. Gower, 35-84. Western Australia: UWA Publishing.

Ramlah Abdul Rahman. 2009. The report of pilot project on curriculum of education among Orang Asli and Penan people. https://jpmipgmtaa.webs.com/Aktiviti_Jabatan/ Laporan\%20KAP\%202009.pdf (accessed 14 May 2014).

Ramle Abdullah, Wan Hasmah Wan Mamat, Wan Ahmad Amir Zal and Asmawi Mohamad Ibrahim. 2013. Teaching and learning problems of the Orang Asli education: Students' perspective. Asian Social Science 9(12): 118-124. https://doi.org/10.5539/ass.v9n12p118

Rigney, L.I. 2007. Our teacher crisis. Koori Mail Edition 417, p.27. https://aiatsis.gov.au/ collection/featured-collections/koori-mail (accessed 23 June 2014). 2010. Indigenous education: The challenge of change. Every Child 16(4): 10-11.

Rohaida Nordin. 2010. Malaysian perspective on human rights. Journal of Law 14: 17-33. Rohaida Nordin and M.A. Witbrodt. 2012. Self-determination of indigenous peoples: The case of Orang Asli. Asia Pacific Law Review 2(2): 189-210. https://doi.org/ 10.1080/10192557.2012.11788260

Rumsey, A. 2012. Language and territoriality in Aboriginal Australia. In Language and cultural in Aboriginal Australia, 5th ed., eds. M. Walsh and C. Yallop, 191-206. Canberra: Aboriginal Studies Press.

Sarjit, S.G., Mohd Roslan Rosnon and Ma'rof Redzuan. 2010. Acculturation of consumerism among the Orang Asli community in Jelebu, Negeri Sembilan. Pertanika Journal Social Sciences and Humanities 18(2): 321-331.

Sharifah Md Nor, Shamsilah Roslan, Aminuddin Mohamed, Kamaruddin Abu Hassan, Mohamad Azhar Mat Ali and Jaimah Abdul Manaf. 2011. Dropout prevention initiatives for Malaysian indigenous Orang Asli children. The International Journal on School Disaffection 8(1): 42-56. https://doi.org/10.18546/IJSD.08.1.07

Sidwell, P. and B. Roger. 2011. The Austroasiatic Urheimat: The Southeastern riverine hypothesis. In Dynamics of human diversity, ed. N.J. Enfield, 317-345. Canberra: Pacific Linguistics. 
Subramaniam, Y. 2011. Rights denied: Orang Asli and rights to participate in decision making in Peninsular Malaysia. Waikato Law Review 19(2): 44-65.

2012. Orang Asli land rights by UNDRIP standards in Peninsular Malaysia: An evaluation and possible reform. PhD diss., University of New South Wales, New South Wales, Australia.

Suruhanjaya Hak Asasi Manusia (SUHAKAM). 2010. SUHAKAM annual report 2010. Kuala Lumpur: SUHAKAM.

2011. SUHAKAM annual report 2011. Kuala Lumpur: SUHAKAM.

2012a. Right to education status for Orang Asli children. Kuala Lumpur: SUHAKAM.

2012b. The status report of child rights education of Orang Asli. Kuala Lumpur: SUHAKAM.

Tay, L.K. 2009. Penglibatan ibu bapa Orang Asli dalam program pra sekolah. In Masyarakat Orang Asli: Perspektif pendidikan dan sosiobudaya, eds. Abdul Razak Ahmad and Zalizan Mohd Jelas, 177-194. Bangi: Universiti Kebangsaan Malaysia.

UNDRIP. 2007. United Nations declaration of the rights of indigenous people. https:/www.un.org/development/desa/indigenouspeoples/wp-content/uploads/ sites/19/2018/11/UNDRIP_E_web.pdf (accessed 24 July 2013).

Wan Zawawi Ibrahim. 1996. Kami bukan anti pembangunan: Bicara Orang Asli menuju Wawasan 2020. Bangi: Persatuan Sains Sosial Malaysia.

Yunupingu, M. 1995. National review of education for Aboriginal and Torres Strait Islander peoples: Final report. Canberra: Australian Government Publishing Service. 